\title{
Book Review: From Natural Law to Political Economy: J.H.G. von Justi on State, Commerce and International Order by Ere Nokkala, Vienna, Lit Verlag, 2019, 312 pages. ISBN: 9783643910356
}

\author{
Martti Koskenniemi \\ Helsinki, FI \\ martti.koskenniemi@helsinki.fi
}

Keywords: Justi J.H.G; cameralism; natural law; history of political thought; legal history

Ever since Michel Foucault cut off the king's head in his studies of ruling in the 1970s, there has been increasing interest among historians in the mundane administrative practices that have formed the contours of the lives of Europeans since the $18^{\text {th }}$ century. In the historiography of European politics and political thought, the theme of 'governmentality' has invited scholars to move their gaze from royal government and official political theories to low-level bureaucratic techniques of measuring and using of the resources available on the territory to strengthen the state against its internal and external rivals. New studies of men like the counter-reformation activist Giovanni Botero and new readings of mercantilism have focused on the rise of the population as a primary resource to be recorded and employed for securing the strength and well-being of the state (Descendre 2009; Stern \& Wennerlind 2014). Older histories of economic thinking tended to regard Adam Smith as the telos of all earlier reflection about the conditions of well-being in a state and a sharp turning point from an abstract and metaphysical natural law towards a 'modern', empirical, and historically oriented political economy, with only few sideways glances to his inevitably obscure French precursors. One of Foucault's achievements was to replace such teleological, and sometimes hagiographic, histories of political economy by attention to a wide range of technical practices of government and connected discourses across the $18^{\text {th }}$ century that have contributed to the emergence of that distinctly modern use of power that gradually would adopt the name of 'the economy'.

One of the places where these discourses were developed in the late- $17^{\text {th }}$ and early- $18^{\text {th }}$ centuries with the greatest intensity was the Holy Roman Empire of the German Nation. At the time, a plethora of small universities emerged across the imperial territory with law schools to produce advisors to the rulers of its petty principalities. The original organization of the university, with the higher faculties of theology, medicine, and law, had always been conceived to prepare students to contribute to what was often called the happiness of the adjoining world. Teaching the skills of government specifically had been divided between theology and law in 
such a way that while the old literary genre of the mirror of princes was assigned to theologians, contemplating the virtues of a good ruler, lawyers were to teach the students about the origin and justification of state power, usually under Aristotelian constitutional categories. The situation changed quite dramatically after Samuel Pufendorf and Christian Thomasius had re-oriented politically relevant thinking about state power towards a non-Aristotelian natural law that took its ideals from the successes of the natural sciences. The University of Halle, established in 1694, became the centre of the most influential natural law teaching in the early $18^{\text {th }}$ century under the commanding figure of the ultra-rationalistic Christian Wolff. But Wolffian rationalism soon received a rival from the university of Göttingen, established in 1734, and programmatically oriented towards empirical theories and techniques of statehood. Topics such as Staatskunst, Staatrecht, Staatsklugheit, and Statistik were taught and classified by Göttingen's leading jurists Johann Stephan Pütter (1725-1807) and Gottfried Achenwall (1719-1772), friends and collaborators in their joint effort to develop natural law into pragmatic science of government, appropriate for a modern fiscal-military state (Streidl 2000).

The science of government that was developed between Halle and Göttingen in the $18^{\text {th }}$ century has sometimes been reduced to a history of the cameral sciences, but the scope of intellectual work was actually much wider and included subjects from the metaphysics of state power to principles of urban development, theories of just war to agricultural modernization, and from what was often called balance of trade to the fiscal techniques enabling the prince to live according to the expected level of ostentation. Cameralism did not fit well in an academic context, and lawyers furiously resisted its integration as an autonomous discipline in university teaching, seeking instead to adapt older policy-science (Policeywissenschaft) so as to include these more concrete techniques. In due course, some it was integrated in administrative law in the $19^{\text {th }}$ century, but most of the materials came to be treated in the novel discipline of Nationalökonomie or Staatswirstchaft. ${ }^{1}$

It was in this environment of intellectual and professional fermentation, with some academic disciplines on their way out, others struggling to get in, with the law school often thinking of itself as the queen of the sciences, that Johann H.G. Justi (1717-1771) entered in the 1750s and 1760s first in Vienna, then in Göttingen and eventually Berlin. Justi has sometimes been regarded a cameralist and at other times an early political economist. Such labels tend to ignore the degree to which boundaries between disciplines inside what would later come to called 'social sciences' were anything but clear at the time. Most of what Justi wrote was in the idiom of natural law, developing towards increasingly concrete and detailed instructions for the government of the various functions of the fiscal-military state, and this is also the starting point of Ere Nokkala's insightful intellectual biography, although his interest is, understandably enough, on the contribution of his protagonist to what later was called political economy. Justi was a complex figure who has not received a favourable treatment in the literature. He wrote an enormous number of thick works, freely plagiarising himself and others, endlessly quoting, and sometimes bluntly contradicting himself. He moved about in the German-speaking universities, and occasionally public administrations, without being able to receive or hold a permanent position, burning bridges to colleagues and superiors, ending his life imprisoned by Frederick the Great out of suspicion (perhaps wrongly) for having misused Prussian state funds in his capacity the state's Berghauptmann.

\footnotetext{
${ }^{1}$ The best English-language history of the development still is Tribe, 1988. Shorter but equally useful is Tribe
} 1995. 
However, Ere Nokkala wants to draw a somewhat brighter picture of Justi, going against much older literature, highlighting the innovative character of aspects of his principal works and the degree to which he moved from an older state-centric, or even prince-centric, idiom to the direction of legal and political thinking where the 'happiness' of the state, the standard Wolffian objective, would be read to include the mercantile freedoms of the subjects as well. Situated in the civil philosophy stream of the German enlightenment, Justi appears here as a theorist of the early modern state (he was a frequent user of the state-machine metaphor), emerging from civic activism instead of a divine grant, a mechanism whose ultimate purpose was to serve its founders, the citizens. Ruling the state was to be seen as separate from, although operating in close relationship to something later thinkers would address as civil society, a realm of individual industry and economic initiative. But Justi was no Adam Smith and despite his insistence on freedom-especially the freedom of the Hausvater-much of his writing still presumed that the State would have a key role in initiating and supporting the creation of welfare, too, alongside the older objective of security.

Nokkala delivers to his readers a much-needed contribution to the history of social sciences, and a partial corrective to the narratives of German enlightenment ideas about statehood and government. He shows that the world of cameralism, policy-science, and natural law at mid- $18^{\text {th }}$ century German universities was more than the rather stereotypical image of the self-important professor churning out open-ended moral truisms or seeking to regulate the tiniest details of lives of the lives of the subjects. Anglophone historians have often been unable to resist the temptation of making fun of the dry conceptualisations and quasiscientific seriousness that went on at $18^{\text {th }}$ century German universities under the labels of cameralism and Policey (e.g. Wakefield 2009). It is time for a more sympathetic treatment of the efforts of men like Justi to think about the conditions of good government in the fragmented and dysfunctional world of the Holy Roman Empire. The old regime was crumbling. The vocabularies of an old, authoritarian world no longer carried conviction. In Nokkala's version, Justi's project may be imagined as a German variant of what was being done by the Physiocrats in France and the empirical moralists in Scotland. The specificity of the German story lay in the decisive role that university professors played in it both as teachers but perhaps, above all, as advisors to the princes to whom they owed their appointment. Their situation, close to and often dependent on the prince, also limited what they could achieve in terms of the reform of the small principality to which they addressed their counsel. Many of these men were mediocre thinkers who kept reproducing dogma taken over from their predecessors. But not all were, and Justi did have a keen sense that what he was trying to deliver was something that especially the 'Wolffians' had failed to produce, namely a realistic sense of the interdependence of the well-being of the rulers and their subjects within the modern state-machine which it was the task of good government to take account of. It's a shame that his insights were hidden in often abstruse and certainly overly long works. With Nokkala's help, however, we can now receive a quick overview and analysis of the principal points where Justi was innovating.

As Nokkala shows, Justi had many things to say about government in an era where state power was increasingly associated with the wealth and happiness of the ruler and his subjects, although he was rarely able to put it in an elegant or fashion. Earlier forms of natural law had been successful because they had provided a plausible justification for state power. The hypotheses of the state of nature, the social contract construction, as well as the view of the state as an instrument for the security and well-being of the subjects had offered a powerful explanation for why the ruler could justifiably demand the obedience of his subjects. But that was a theory to justify state power. It had little to say about how that power was to be 
used to as to fulfil what the theory addressed as the 'state purpose', 'Staatszweck. It was this problem that cameralism, policy-science, and eventually Justi's elaborations on the operations of the 'state-machine' were addressed. Nokkala focuses above all on three aspects of Justi's works: his analysis of passion and desire as the fundaments of human behaviour; his instrumental view of the state-machine at the service of civil society; and his critical view of the present international political and commercial order.

What separates Justi from run of the mill cameralists was the breadth of his ambition. Justi brought his detailed elaborations of good policy within an overall naturalist metaphysic of statehood. His Natur und Wesen der Staaten als die Quelle der Regierugnswissenchaften und Gesezze ('The Nature of States as Sources for the Sciences of Government and Legislation', 1771) situated his practical recommendations firmly in the stream of German natural law, with ample and often critical references to Montesquieu. Emphasising the situatedness of Justi's writings in a legal tradition is especially important as Nokkala has titled his work in terms of a passage from natural law to political economy. This is not wrong, but perhaps a little too teleological, obscuring the degree to which what later came to be addressed as political economy (an expression likely to have been popularised by James Steuart in the 1760s) embodied a sturdy normative centre familiar from and continuous with the project of natural law. It is right to say that in the German realm it was Justi who put forward the assumption that there was an intrinsic normativity in production, manufacturing and commerce that, if taken due heed of, and allowed to operate in relative independence from the fiscal needs of the state, might provide the best results for both for the prince and his subjects. But Justi was trained as a lawyer in Göttingen and imagined what he was doing as part of the stream of natural law, though he did believe that for a state government, it was not sufficient to hire lawyers, but one also needed universal cameralists, men who would be knowledgeable about how to use the resources of the state. Something like 'political economy' was not really open for Justi, although the fact that he used ambiguous formula and frequently contradicted himself must have reflected the real difficulty at the time of interpreting the way states were developing in their relationship to the adjoining society where the relations between families and their members, mercantile actors, and official bureaucrats were still read within a traditional, largely religious frame.

Perhaps the most original aspect of Nokkala's analysis is the link he makes between Justi's speculations about passion and self-interest as the fundamental aspects of human nature and the 'new' natural law theory propagated by one of Wolff's detractors in Göttingen, Johann Jacob Schmauss (1690-1757), court counsellor at Baden-Durlach, advisor, diplomat, and representative of the Bishop of Strasbourg in the imperial Diet. Schmauss had been recruited to teach the law of nature and of nations though he had little to do with the subject earlier. Hence, he would appear as a reformer, writing freely on the 'true concept' or 'new system' of natural law, where he argued that the most important of the drives determining human behaviour was self-preservation. Reason was a secondary pendant of culture and calculation. Drives gave rise to fear and hope, and it was the latter that directed the will to choose well'like the traveller chooses the safe road through a forest with wild animals' (Schmauss 1754, Grunert 2004). This provided a purely factual, rather than normative, basis for natural law. The drives were accompanied by corresponding rights and freedoms: the instinct of self-preservation came with a right of self-preservation, including a subjective right to everything that contributed to that purpose. This created a wide sphere of individual freedom: at one point, Schmauss even suggested that as large fish have the natural drive of eating small ones, it followed that they 'undoubtedly' had the right to this, too (Schmauss 1754, 472).

The 'New System' of Schmauss included an extensive list of innate freedoms and rights (iura connata) that belonged to all humans in the natural state. In addition to self-preservation, 
these included freedom and equality, the right to equal respect, the rights of self-defence, and the right to occupy ownerless things and to dispose of them in accordance with what was necessary and useful. Nokkala suggests that these views were taken over by Justi and translated into the background conditions and driving themes of the altogether 69 massive volumes he produced in his lifetime. Schmauss, who died young and whose Hobbesian naturalism was regarded with suspicion by the more orthodox Wolffians, never received Justi's notoriety. It is an interesting and important connection that Nokkala here weaves between the Hobbesian Schmauss and the early steps of a professional analysis of an autonomous field of economic transactions in civil society.

According to Nokkala, Justi's detailed elaborations ought to be read as an effort to revise the orientation of natural law from Wolffian rationalism to Schmaussian emphasis on passion and drives as the motivating factors for human action. The principal revision concerns reading the standard tropes of 'State purpose' (Staatszweck) and 'happiness' (Glückseligkeit) from the provision of security towards enabling the citizens, or at least families, to live in freedom in civil society. Although Nokkala stresses that unlike many earlier jurists, Justi was no friend of authoritarianism, he did not mean political but 'only' civil freedom. There was never any sense that citizens ought to be allowed to participate in public decision-making as well. But the emphasis on the rights of the subjects, or at least the heads of families to decide on their livelihood-to live in accordance with their will, as was the naturalist formulation-signified an attack against the leading role of the estates and corporations in society, as well as a rejection of serfdom, steps towards acknowledging the equality of members of civil society and a meritocratic view of government. Justi did not share the Montesquieu's view of nobility, an important balancing feature in public life. A free citizen and the pillar of a well-governed state was a Wirtschaftbürger.

Justi was frequent user of the metaphor of the 'state-machine'. This much-studied metaphor denoted the effort to inaugurate an empirical study of statehood that could be conceived analogously to the natural science (Stollberg-Rilinger). Whether as a 'machine' or a 'body', the state could be conceived as an autonomous system that could be employed for the accomplishment of specific tasks. This would turn government and ruling into technologies (as Foucault and others have suggested), an idea that both Hobbes and French Physiocrats, such as Pierre Le Mercier de la Rivière, had suggested. Justi did not seem to have put forward a very clear view of how he would employ that metaphor. Nokkala discusses his use of it in terms of Justi's quite puzzling simultaneous admiration of both China and England-very different systems of government, though both characterised in Justi's mind with their success. Justi's was sceptical about constitutional architectonics. 'Absolutist' and 'free' states could operate equally efficiently; everything depended on their specific histories, the character of the people and the resources available for producing a workable balance between the drives of security, wealth, and freedom for which the state was established. Nokkala is keen to avoid the conclusion that such contemplations lead inevitably to authoritarianism. Instead, he integrates Justi's view of human drives into the state-machine itself, called upon to organise the 'mainsprings' of human action into a well-functioning balance. The description of the state as a balancing device with respect to the drives of the subjects resonates, as it may have been supposed to do, with the present-day experience of late-modern states as mechanisms for balancing subjective rights. The way in which Schmauss (and perhaps Justi, too) translated drives into rights (we have a right to what we have an inclination to) would speak volumes if used as a basis for reflecting the fate of today's rights culture.

One suspects that Justi's positions may sometimes have emerged from his contrarian tendency to develop polemical counter-positions to the works of more conventional colleagues. This may be so at least with regard to his defence of the notion of 'universal monarchy', 
otherwise everywhere used as a negative characterisation of French foreign policy ambitions. It is true that many respected European thinkers from Dante to Abbé de Saint Pierre and even Wolff (whose idea of the Civitas Maxima Justi nevertheless rejected) had suggested large federal union as the only mean for durable peace in Europe. The image of Roman glory was never far from the subconscious of European thinkers. But anyway, that idea went nowhere. Much more interesting was Justi's critique of the chimera of the balance of power, and especially the connected idea of such balance in regard to trade. During the Seven Years' War, the French had tried to rally Prussia against British commercial hegemony by proposing that alongside the balance of power, a well-established part of what diplomats called the public law of Europe, there ought also be a 'balance of trade'. England ought to be seen to have attained its hegemony illegally. Justi drew attention to the irrationality and utter injustice of such a suggestion (Justi 1769). The argument accepted that state power was above all commercial power. But commercial power could not be limited in the way suggested by the French. It was the nature of commerce to be free. Every nation tried to export as much as it could and to buy what it needed from whomsoever was willing to sell at the lowest price. Success in such dealings depended on the industry and skilfulness of the population and power increased naturally as economic contacts expanded. The proposal did not only strike at the commercially successful nation but also the presumably 'innocent' nation that traded with it. The French proposal, Justi concluded, was merely a hypocritical effort to dress France's military interests in the form a principle of European public law.

Justi's arguments in the 'Chimera of the Balance of Trade' were especially interesting because they drew a sharp divide between politics and the economy, describing the latter in terms of a global market where all nations competed to the best of their capacities. To limit this would arbitrarily curtail the expansion of resourceful and industrious countries and, as Justi suggested, also failed to have regard to the fact that there was a natural balancing aspect in trade itself. The more successful a nation was, the more there would be money circulating in it, and the more the salaries would rise and the more expensive its goods would become. With such arguments Justi separated the operation of international economy from the policies of European States precisely at the moment he was joining the period's political thinkers in regarding economic strength the most vital aspects of a state's power.

Nokkala's book provides a welcome corrective to the literatures about the history of governmentality and the related but less prolific examination of the conflict of the facultiesthe clash and competition between expert languages in the early modern period seeking to justify and thus partake governmental authority in a post-theological era. How to integrate human needs and wants into a rational theory of state purpose? How to organise the state so that it is able to fulfil those purposes most efficiently? Although Justi's works were written largely in a legal idiom, his analysis of state power moved gradually away from public law and sovereignty-useful to justify the existence of states but less so as directives for good government. State power could no longer be thought in terms of territorial scope. Belligerent policy and looking for the glory of the ruler were the wrong way to go. Instead, focus needed to be on how the domestic resources could be put to efficient use in view of the needs and capacities of the population. Although the role of the state remained central, wealth-creation could not be only about the regulation of the lives of citizens. Instead, the state might often provide room for the families themselves to plan their livelihood, engage in production and exchange their goods in opens markets at home and abroad. It is a great benefit of this work that Nokkala has not reduced Justi into yet another 'precursor' to Adam Smith and the theorists of the neoclassical economy. His arguments moved within a wholly different historical and intellectual context. The available disciplinary alternatives and political institutions required a more rationalist and law-centric argument than the Scottish enlighteners focus on moral 
sense. The ability to exploit resources in an ever-widening imperial realm created conditions that were not available in Germany where the focus of some of the most imaginative social thinking would continue to focus on public law and the relations between state and society.

Nokkala's work is a welcome contribution to the historical study of the moment when something like 'political economy' began to claim authority on how social power ought to be distributed in the conditions of early modernity. It is interesting to view how the legal-normative voice of older natural law accommodates itself with instrumental-technical considerations, and the other way around. Justi was rehearsing a new idiom, whose ambiguities would be clarified and contradictions removed until it would no longer sound legal-normative at all. So far, that story has been hidden in the often marginal and teleological literatures that go by the name of history of economic thought. But a change has been under way for some time, perhaps speeded up after Piketty and others have began to open the case of curiosities that goes by the name of neoliberalism. In this history, Justi has an important place and it is to Nokkala's credit that he has noticed this and brought Just from the margins of that 'dismal science' to its centre.

\section{Competing Interests}

The author has no competing interests to declare.

\section{References}

Descendre, Romain. 2009. L'état du monde. Giovanni Botero entre raison d'état et géopolitique. Genève: Droz.

Grunert, Frank. 2004. "Das Recht der Natur als Recht des Gefühls: Zur Naturrechtslehre von Johann Jakob Schmauss". Annual Review of Law and Ethics 12: 139-153.

Justi, Johann Heinrich Gottlob. 1769. Die Chimäre des Gleichgewichts der Handlung und Schiffahrt. Altona: Iverse.

Schmauss, Johann Jacob. 1754. Neues Systema der Rechts der Natur. Göttingen: Vandenhoeck.

Stern, Philip, and Carl Wennerlind (eds). 2014. Mercantilism Reimagined. Political Economy in Early Modern Britain and its Empire. Oxford: Oxford University Press. DOI: https://doi. org/10.1093/acprof:oso/9780199988532.001.0001

Stollberg-Rilinger, Barbara. 1986. Der Staat als Machine. Zur politischen Metaphorik des absoluten Fürstenstaats. Berlin: Duncker \& Humblot. DOI: https://doi.org/10.3790/978-3428-06022-1

Streidl, Paul. 2000. Naturrecht, Staatswissenschaften und Politisierung bei Gottfried Achenwall (11719-1772). Studien zur Gelehrtengeschichte Göttingens in der Aufklärung. Munich: Utz.

Tribe, Keith. 1988. Governing Economy. The Reformation of German Economic Discourse 1750-1840. Cambridge: Cambridge University Press.

Tribe, Keith. 1995. Strategies of Economic Order 1750-1950. Cambridge: Cambridge University Press. DOI: https://doi.org/10.1017/CBO9780511551529

Wakefield, Andre. 2009. The Disordered Police State: German Cameralism as Science and Practice. Chicago: Chicago University Press. DOI: https://doi.org/10.7208/ chicago/9780226870229.001.0001 
How to cite this article: Koskenniemi, Martti. 2020. "Book Review: From Natural Law to Political Economy: J.H.G. von Justi on State, Commerce and International Order by Ere Nokkala, Vienna, Lit Verlag, 2019, 312 pages. ISBN: 9783643910356." Redescriptions: Political Thought, Conceptual History and Feminist Theory 23(1): 71-78. DOI: https://doi.org/10.33134/rds.328

Submitted: 04 June 2020 Accepted: 04 June $2020 \quad$ Published: 13 July 2020

Copyright: (c) 2020 The Author(s). This is an open-access article distributed under the terms of the Creative Commons Attribution 4.0 International License (CC-BY 4.0), which permits unrestricted use, distribution, and reproduction in any medium, provided the original author and source are credited. See http://creativecommons.org/licenses/by/4.0/.

Redescriptions: Political Thought, Conceptual History and

HUP MPNINESKIT Feminist Theory is a peer-reviewed open access journal

OPEN ACCESS $\precsim$ published by Helsinki University Press. 